\title{
塩釡港棧橋の電気防蝕基礎試験
}

\author{
遠藤 出*，山下 勝*，筧 建 彥*
}

\section{A Fundamental Test on Cathodic protection in Shiogama-port}

Izuru Endo, Masaru Yamashita \& Takehiko Kakei.

A fundamental test on cathodic protection of steel pier in Shiogama-Port was carried out. From the test it was found that (1) the current required for protesteel piles and sheet piles surface, (2) a current from ction was about $100 \mathrm{~A}$ against $2,000 \mathrm{sq}$. meter of

one direct current source unit with 6 magnetite anodes burried or hung under the pier fully protected 24 steel piles, and (3) in that case the current distribution was very satisfactory.

し大体 5〜 7゚ C の範四に出つた。なせ試料採取時の海中 に括ける温度分布は海佰で海底で $2.8^{\circ} \mathrm{C}$, 海底て $2.5^{`} \mathrm{C}$,

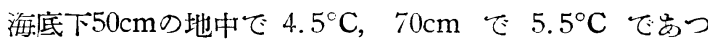
た。また海水試料の $\mathrm{pH}$ を Wulff 氏式篎比色計により 実測した結果は後に述べる。

第2 表 海底泥土 No.3 による鉄ひ腐鏹試験

\begin{tabular}{|c|c|c|c|c|c|}
\hline $\begin{array}{c}\text { 電流密度 } \\
\mathrm{A} / \mathrm{m}^{2}\end{array}$ & $\begin{array}{c}\text { 腐饂減量 } \\
\mathrm{g}\end{array}$ & $\begin{array}{l}\text { 㢈咀 度 } \\
\mathrm{g} / \mathrm{m}^{2} / \mathrm{hr}\end{array}$ & $\begin{array}{l}\text { 伎飿，度 } \\
\mathrm{mm}_{\text {/ }} \mathrm{yr}\end{array}$ & $\begin{array}{l}\text { 防 飿 } \\
\%\end{array}$ & $\begin{array}{l}\text { 㷛率 } \\
\%\end{array}$ \\
\hline 0 & 0.0030 & 0.0210 & 0.0230 & & 0 \\
\hline 0.10 & 0.0005 & 0.0034 & 0.0038 & & 83.7 \\
\hline 0.15 & 0.0004 & 0.0030 & 0.0033 & & 85.6 \\
\hline 0.20 & 0.0003 & 0.0021 & 0.0023 & & 90.0 \\
\hline 0.30 & 0.0002 & 0.0014 & 0.0016 & & 93.3 \\
\hline
\end{tabular}

試片表面積 $10 \mathrm{~cm}^{2}$, 通䉓時閌 $146 \mathrm{hr}$

塩忞港つ現地より持帰つた試料**（海水扣よび海底土 壤つについて，実験室においてその中数枚の鉄試片を 浸漬し, 各片に種々の除極電流密度で通電する方法によ つて鹰蝕試験を行い，また真空管電位差計を使用して鉄 の分極電位測定を行つた。実験装置の概要および実験結 果を第1〜2表ふよび第2４図に示す。試験温度は室温と

第 1 表 海水 No.1 による鉄の腐飿試験

\begin{tabular}{|c|c|c|c|c|}
\hline $\begin{array}{c}\text { 電流密度 } \\
\mathrm{A} / \mathrm{m}^{2}\end{array}$ & $\begin{array}{c}\text { 鹰飿減量 } \\
\mathrm{g}\end{array}$ & $\begin{array}{l}\text { 腐 领度 } \\
\mathrm{g} / \mathrm{m}^{2} / \mathrm{hr}\end{array}$ & $\begin{array}{c}\text { 侵 領 度 } \\
\mathrm{umm} / \mathrm{yr}\end{array}$ & $\begin{array}{c}\text { 防 䭙率 } \\
\%\end{array}$ \\
\hline 0 & 0.0072 & 0.124 & 0.138 & 0 \\
\hline 0.10 & 0.0012 & 0.020 & 0.022 & 83.8 \\
\hline 0.15 & 0.0020 & 0.018 & 0.020 & 85.4 \\
\hline 0.20 & 0.0008 & 0.014 & 0.016 & 88.6 \\
\hline 0.30 & 0.0006 & 0.011 & 0.012 & 91.0 \\
\hline
\end{tabular}

試片䘚面積 $5 \mathrm{~cm}^{2}$, 通電時間 $116 \mathrm{hr}$

防领率 $=$ 不通電試片の腐刢度一通電試片の腐蝕度 不通電試片の鹰蝕度
○娒水160: 以上の実験室試験の結果 を現地実駼の基礎資料とし

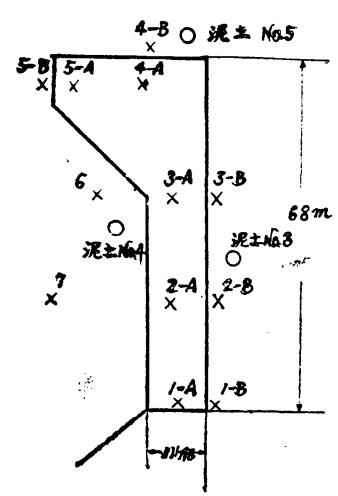

第 1 図 海水扣よび土堷採取位置 ○ 海水泥土採取位罚 $\times \mathrm{pH}$ - 比抵抗測定試䉼採取位置 て考察した。その要点を次 に摘記する。

(1) 現地海水によこ腐蝕 試験では二つの試料のデー タに多少のバラッキがある が大差なく，防蝕しない試 片の腐钫度に比較して涌電 した試片は充分な防強效果 の場合鉄の電位を 通電前の電位上り 子 $0.2 \sim 0.3 \mathrm{~V}$ 程 庤引き下の余裕を 見ても $0.1 \mathrm{~A} / \mathrm{m}^{2} て ゙$ 海水No.2O を示している。こ 


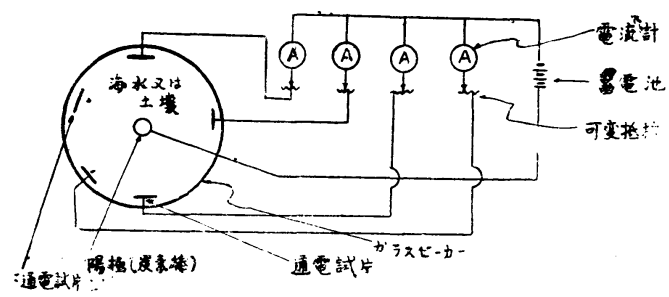

管 2 図 実験室試験装置

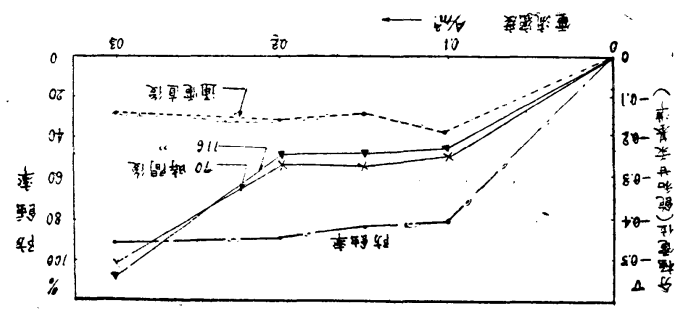

第3図 海水No.1による鉄の㓌極分極々防飭率

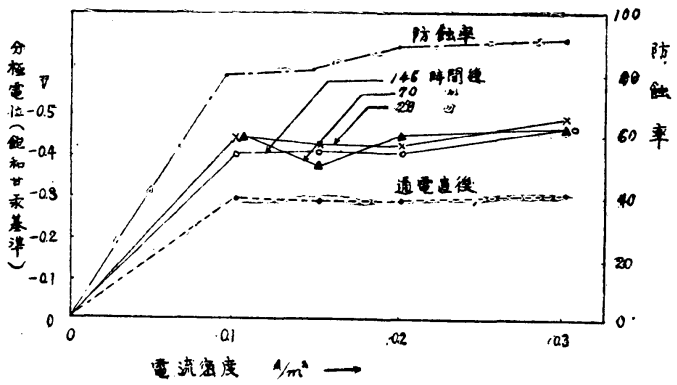

第 4 図海底土No.3による鉄の除極分極々防飿率

げることが必要と認められる。

(2)上記の場合防玲電流は $0.1 \sim 0.2 \mathrm{~A} / \mathrm{m}^{2}$ を必要とする。

（3）海水を含む泥土中における腐玲度は海水中のそれ の約 $1 / 3$ である。したがつてこの防蝕に要する電流は相当
充分である。

\section{2. 現場実驗および調查}

以上の結果にもとづいて防蝕に必要な電流密度を一応 $0.1 \mathrm{~A} / \mathrm{m}^{2}$ と推定し, 鋼杭 (径 $32 \mathrm{~cm}$, 長さ $10 \mathrm{~m}$ ) 1 本の 表面廭を約 $10 \mathrm{~m}^{2}$ と与ると，鋼杭 161 本の防虽面廭(約 $1,600 \mathrm{~m}^{2}$, また鋼矢板 (長さ $12 \mathrm{~m}$ ) 延長 $25 \mathrm{~m} \sigma$ 防俞面積 は約 $400 \mathrm{~m}^{2}$, したがつて被防蝕表面積!合計約 $2,000 \mathrm{~m}^{2}$ となる。なお杭基盤目状に約 $3 \mathrm{~m}$ の間隔で配置されて いる。こ礼に対して電流分布の均一性を考慮して電極の 使用数を48本とし，その電極 6 本を 1 組としてこれが受 持つ防钟表面積を約 $24.0 \mathrm{~m}^{2}$ ，即ち鋼杭24本とした。した がつて現場実験の対象としてまず鋼杭24本を考え，これ を仮設霓線にて第 7 図の如く互に連結し，これに6本の 磁性酸化鉄電極を配して約24Aの電流を供給する方針と し，下記要領により実験する計画を立案した。なお直流 電源として電動直流発電機を用いた。

\section{(1) 実験要項}

(a) 通電前 (自然の状態)に打ける電位の测定(飽和 甘承電極および真空管電位差計を使用)

(b) 防蝕限界電位 (飽和甘承基準一0.77V) を達成与 るのに必要な電流およで電圧を求める。このため試験的， 通電の場合に拈ける各珫の電位を測走する。

(c) 各電極ごとに流れる電流の測定 .

(d) 電㥛数を減少した場合の電位分布および電流，電: 圧の関係

\section{(2) 調查要項}

(a) 第 1 図指定の地点における土壊および海水の比抵 抗と $\mathrm{pH}$ の測定

(b) 電極および鋼杭の接地抵抗の測定〔コールラウシ

第3表海水扣よど土壊の比抵抗測定

\begin{tabular}{|c|c|c|c|c|c|c|c|c|c|c|c|c|c|}
\hline \multirow{2}{*}{\multicolumn{2}{|c|}{ 採取場 所 }} & \multicolumn{2}{|l|}{1} & \multicolumn{2}{|l|}{2} & \multicolumn{2}{|l|}{3} & \multicolumn{2}{|c|}{4} & \multicolumn{2}{|c|}{5} & \multirow[t]{2}{*}{6} & \multirow[t]{2}{*}{7} \\
\hline & & A & B & A & B & A & B & A & B & A & B & & \\
\hline 海 & $\begin{array}{l}\mathrm{W} \\
(\Omega)\end{array}$ & - & - & 196 & 156 & 209 & 148 & - & 156 & 190 & - & 208 & 184. \\
\hline & $\left(\begin{array}{c}\rho \\
\Omega-\mathrm{cm}\end{array}\right)$ & - & - & 31.8 & 25.3 & 34 & 24 & - & 25.3 & 30.9 & - & 33.8 & 30 \\
\hline & $\mathrm{pH}$ & - & - & 7.5 & 8.3 & 7.2 & 7.0 & - & 7.0 & 7.0 & - & 7.3 & 7.1 \\
\hline 水 & $\begin{array}{c}\text { 測定温度 } \\
\left({ }^{\circ} \mathrm{C}\right)\end{array}$ & - & - & 7.7 & 7.1 & 7.1 & 7.5 & - & 5.0 & 5.0 & - & 6.0 & 6.0 \\
\hline 土 & $\begin{array}{l}W \\
(\Omega)\end{array}$ & $41^{*}$ & $33 *$ & 81 & $31^{*}$ & 92 & $29 *$ & $3 \% *$ & 91 & - & $38 *$ & 96 & 93 \\
\hline & $\left(\begin{array}{c}0 \\
(\Omega-\mathrm{cm}\end{array}\right)$ & 119.3 & 96 & 235.5 & 90 & 267 & 84.3 & 100.8 & 264.5 & - & 110.3 & 279 & 270 \\
\hline 壞 & $\begin{array}{c}\text { 測定温度 } \\
\left({ }^{\circ} \mathrm{C}\right)\end{array}$ & & & 10.0 & 90 & 10.0 & 8.8 & 9.0 & 2.3 & 2.5 & 4.0 & 2.5 & 25 \\
\hline
\end{tabular}

表中の*は粘土質土壤を示す。測定器の容器恒数を C，コールラウシュブリッジによる澌定值をW $\Omega$ ，比電導度 をRとすると比抵抗 $\rho=1 / \mathrm{R}=\mathrm{W} / \mathrm{C}$ ただしU字管：C=6.15, 土噮隶：C=0.34 
第 4 表 鋼梳および電極の接地抵抗测定

\begin{tabular}{|c|c|c|}
\hline & 鋼 $^{(13-\ldots)^{\text {杭 }}}$ & 電 \\
\hline $\mathrm{R}_{1}$ & $2.2 \Omega$ & $1.4 \Omega$ \\
$\mathrm{R}_{2}$ & 1.6 & 1.7 \\
$\mathrm{R}_{3}$ & 1.0 & 1.7 \\
\hline 接地抵 抗 & 0.2 & 1.0 \\
\hline
\end{tabular}

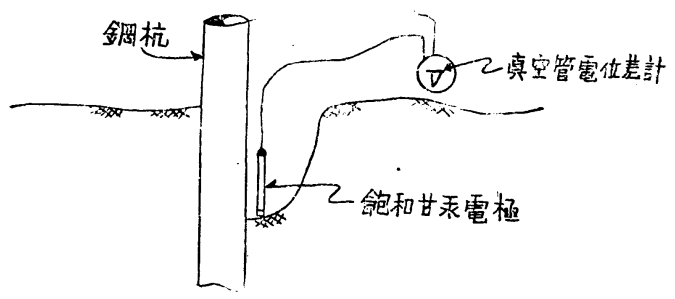

第 5 図電 位 9 測 定

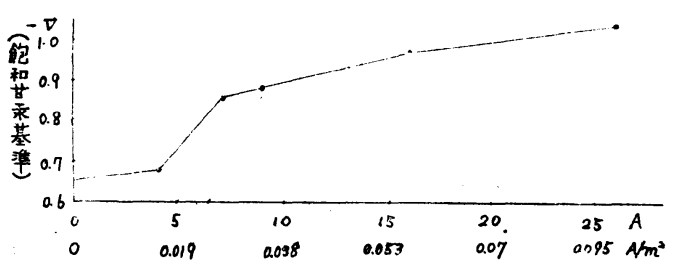

第6 図鋼杭の電極電位 120 ３

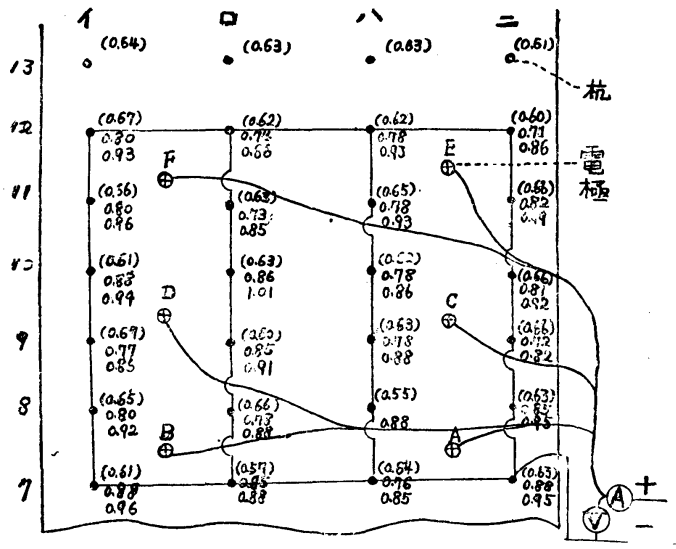

第 7 図 通電試験に昍ける電位(1)数字は上段の括弧 内は不通電；中段は $5 \mathrm{~V}, 7 \mathrm{~A}$; 下段は 7.5 $\mathrm{V}, 14 \mathrm{~A}$ の場合に扣ける各負電位

ユブリッジ使用う

これは第 9 図に示寸如く测定しようとする電極或いは鋼 杭から相互に10mの間隔でほよ゙正三角形になるように2 本の補助接地を設けコールラウシュブリッジでそれぞれ の接地極間の抵抗 $\mathrm{R}_{1}, \mathrm{R}_{2}, \mathrm{R}_{3}$, を測定すると，被測定 物の接地抵抗 $\mathrm{E}_{X}$ は $\mathrm{E}_{X}=1 / 2\left(\mathrm{R}_{2}+\mathrm{R}_{3}-\mathrm{R}_{1}\right)$ で算出され
る。

（c） その他電源，配線等に関する事項

以上の実験および調查の具体的方法とその主要な結果 は第3〜4表および第5〜9図に示生。

\section{3. 結 論}

現地実験およで調查に基ずいて判明した電気防蝕設計 の基礎となる事項活次の通りである。

(1) 鋼杭に法鉛丹系船底塗料が塗つてあるが，杭打込 の際の摩擦により相当制離していると考えられる。しか し塗料はな打相当の防蝕効果を有しているもののごと く, 腐蝕の進行は裸の状態に比して減少している。

(2) 防蝕に必琶な電流は杭24本につき $12 \mathrm{~A}$, 寸なわち (25頁に繶く)

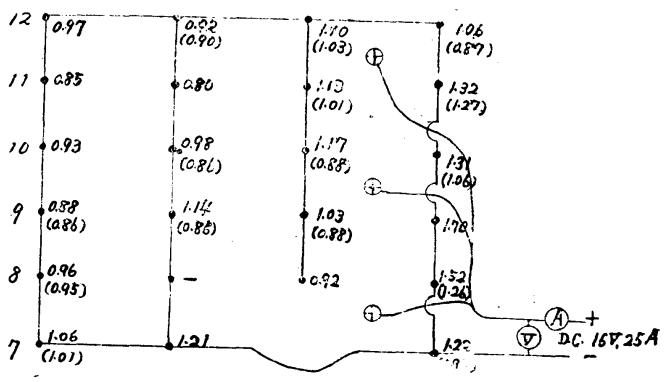

第 8 図 通電試験に扣りる電位(2)

数字は杭の電極側表面の電位を示す。括弧内 は電極反対側の電位。
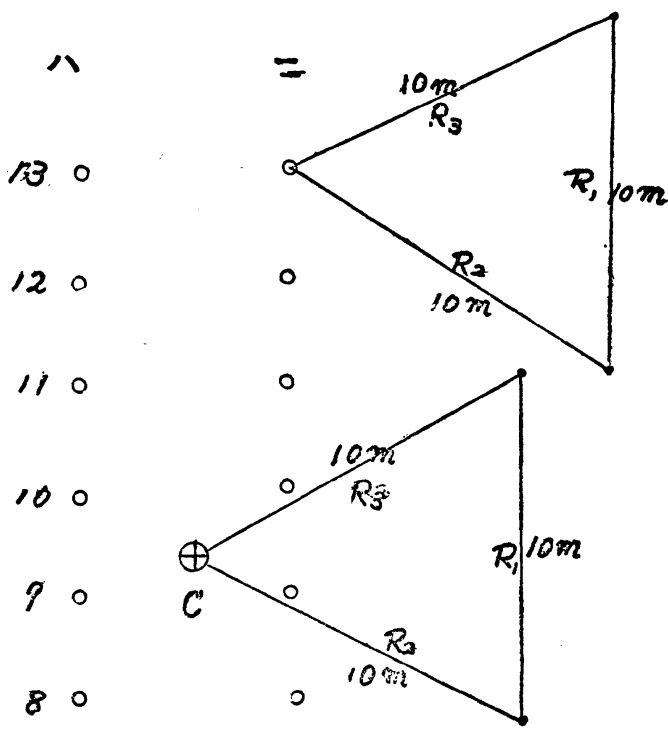

$7 \circ$

$\circ$

第 9 図 銅杭和よび電極の接地抵抗測定

○鋼杭，巴電極 ○補助接地棒 $[\phi 9 \mathrm{~mm} \times 1.5 \mathrm{~m}$ 軟銅 $]$ 
A表代表的アンモニア蒸溜器に括ける試験結果

\begin{tabular}{|c|c|c|c|}
\hline \multirow{2}{*}{ 材料 } & \multicolumn{3}{|c|}{ 府 领 量 in yr. } \\
\hline & I 号試験 & II 号試験 & 目号試験 \\
\hline インコネル & $\mathrm{a}<0.0301$ & $<0.0301$ & 0.0001 \\
\hline 316 ステンレス & $\mathrm{b}<0.0301$ & $a<0.0701$ & $<0.0001$ \\
\hline 304 ステンレス & $c<0.0701$ & $a<0.0301$ & $<0.0301$ \\
\hline 430 ステンレス & 0.001 & $\mathrm{~b}<0.0301$ & $a<0.0301$ \\
\hline 410 ステンレス & d 0.002 & $\mathrm{~b}<0.0301$ & $a<0.0301$ \\
\hline モ 元 & e 0.004 & 0.0305 & $g>0.040$ \\
\hline ニツケル & c $\quad 0.0706$ & 0.0306 & $g>0.040$ \\
\hline ニレジスト而 & 0.001 & $<0.0301$ & 0.022 \\
\hline 軟 & 0.009 & 0.001 & 0.005 \\
\hline
\end{tabular}

試験期間 144 日

I 号試験 fixed Still の底部

II 号試験 free leg $\sigma$ 底部

西号試験 $\mathrm{NH}_{3}$ 蒸気管の free leg ひ顶部

a バラバラの点刢(深さ 0.002 ”程度)

b 全般的点刢 (深さ $0.008^{\prime \prime}$ 程度)

c 全般的点蚛 (深さ0.012"程度)

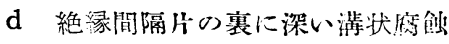

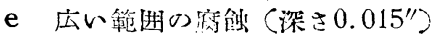

g 試験片が完全に摩飭により消失
B衰

\begin{tabular}{|c|c|c|c|}
\hline \multirow{2}{*}{ 秋 } & \multicolumn{3}{|c|}{ 徱 领 量 in'yr. } \\
\hline & I 号試験 & II 是試験 & 而号試験 \\
\hline 純 & 0.009 & 0.009 & 0.003 \\
\hline アンチモン系鉛 & 0.010 & 0.008 & 0.002 \\
\hline テルリウム鉊 & 0.010 & 0.009 & 0.005 \\
\hline カーペンター20 & 0.017 & 0.012 & 0.002 \\
\hline モ ネ ル & 0.026 & 0.021 & 0.017 \\
\hline 10\% Al 靑 銅 & 0.032 & 0.029 & 0.021 \\
\hline 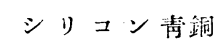 & 0.033 & 0.032 & 0.027 \\
\hline 304 ステンレス & 0.073 & 0.020 & 0.077 \\
\hline 316 ステンレス & 0.090 & 0.087 & 0.015 \\
\hline インコネル & 0.087 & 0.078 & 0.033 \\
\hline$=ツ$ ル & $>0.14$ a & 0.093 & 0.070 \\
\hline 430 ステンレス & $>0.14 \mathrm{a}$ & $>0.14 \mathrm{a}$ & 0.102 \\
\hline キル ド 鋼 & 0.22 & 0.16 & 0.082 \\
\hline ニレジスト & 0.22 & 0.17 & 0.013 \\
\hline 蠟 鋳 & 0.38 & 0.36 & \\
\hline
\end{tabular}

I 号試験 凹推下端に裝借

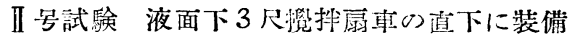

目の試験 液面の上方飛沫のかかる場所に裝借

a $0.031 "$ 片が完全に侵された

\section{( 18 頁からの䋁き)}

\section{文献}

(1) Carl Benedicks. Action of Hot Wall. Trans. Am. Inst. Min. \& Met. Eng. 7, 597, (1925)

(2) H. A. Trebler, W. A. Wesley \& F.L.Laque Corrosin of Metals by Milk, Industrial Engineering Che. mistry, 24, 339 (1932)

(3) Z. Friend and B. B.Knapł “塩酸扮上び塩化永素 中に打けるニッヶル，高ニッヶル合金の寉飭” Trarrs. Am. Inst of Chem. Engineers. 39, 731 (1943)

\section{参䊉資 料}

A : American Petroleum Institute一石油浄化過程に抽 ける腐领試就替定（1930)

B : Symposium on Corrosion Testing Procedures-米 国材料試験協会出版物 (1937)

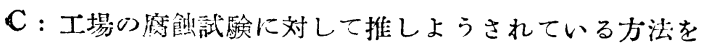
集めた文献山，A224-41，American Society for Testing Materials Standards, (1942) Part1 492

D : 非鉄金属の全面的漫清试験の方法 B185-43TAmerican Society for Testing Materials. Standards. (1943) Part 1332

\section{(33頁からの続き)}

約 $0.05 \mathrm{~A} / \mathrm{m}^{2}$ とい5計画の約 $50 \%$ の電流で充分防蝕可能 であり，電流分布はこの場合㥛めて县好であること晒 められた。

（3ここの時の電源琵圧は約 $7.5 \mathrm{~V}$ を要したが，釟際の

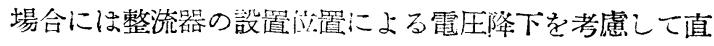
流電源出力電圧を增加し, 尊舶の太さも経済的見地から 選定する必要が点る。

(4) 電㥛数を米”或した星合には沂要の電流およで電位 分布を得るのに電圧が飛躍的に埧加するので雪源整流器 の容量の点で不利である。

(5) 枕の接地抵抗は約 $0.2 \Omega$ で, 庭好と考えられる。 珫と杭との接殻抵抗は I ビーム熔努で㥛めて小さく，ま 注電㥛の接地抵抗引電㥛自身の内部抵抗を含めて約 $1 \Omega$

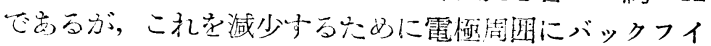
ルを䈯く方が二層有利で怘る。

(6)地盤上部の海水圭食光仯よりも下部泥土質のおが 電導度家良好で号る。

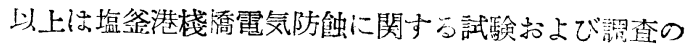
概要を述べたものであるが，本调查に当つてに現地塩釜 港工事々務所長はじめ職員各位の絶大なる御協力を賜わ り，また日本大学工学部山本洋一博士および東京工業試 験所第 4 部重野隼太技官の御指導䘮深く感謝します。 